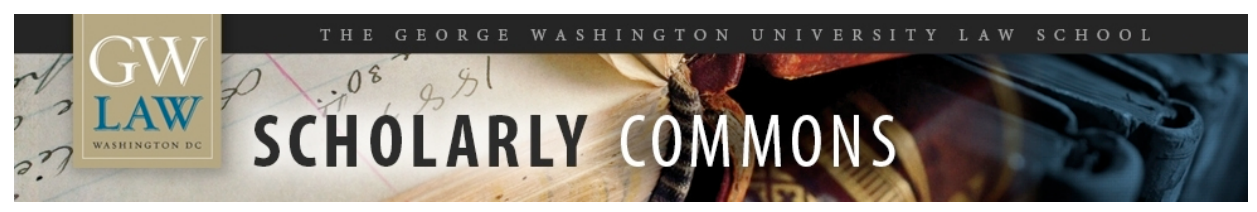

\title{
Economic Development and the Rights Hypothesis: The China Problem
}

Donald C. Clarke

George Washington University Law School, dclarke@law.gwu.edu

Follow this and additional works at: https://scholarship.law.gwu.edu/faculty_publications

Part of the Law Commons

\section{Recommended Citation}

51 Am. J. Comp. L 89 (2003)

This Article is brought to you for free and open access by the Faculty Scholarship at Scholarly Commons. It has been accepted for inclusion in GW Law Faculty Publications \& Other Works by an authorized administrator of Scholarly Commons. For more information, please contact spagel@law.gwu.edu. 
DONALD C. CLARKE

\section{Economic Development and the Rights Hypothesis: The China Problem}

\section{INTRODUCTION}

An important school of thought in institutional economics holds that economic growth requires a legal order offering stable and predictable rights of property and contract because the absence of such rights discourages investment and specialization. In general, the legal order described by this school is something along the lines of the legal systems of the developed countries of the West (excluding Japan, which is rarely discussed). I will call this proposition the "Rights Hypothesis." Without the security of expectations offered by such a legal order, according to the Rights Hypothesis, the risks of a great number of otherwise beneficial transactions far outweigh their expected return, and as a result such transactions simply do not occur. Society is mired in an economy of short-term deals between actors bound by non-legal ties such as family solidarity which by their nature cannot bind large numbers of strangers. ${ }^{1}$

The best known discussion of the relationship between legal institutions and the economy is, of course, Max Weber's. ${ }^{2}$ A classic Weberian formulation of the role of legal institutions in the economy states: "The universal predominance of the market consociation requires ... a legal system the functioning of which is calculable in accordance with rational rules." 3 (As will be shown later, this is not exactly the Rights Hypothesis in its most ambitious form.) The law and development movement in the 1960s produced a great deal of literature advancing the view that "through institutions such as contract and private property rights, modern law promotes the develop-

Donald C. Clarke is Professor of Law at the University of Washington School of Law.

1. See Knack \& Keefer, "Institutions and Economic Performance: Cross-Country Tests Using Alternative Institutional Measures," 7 Econ. \& Pol. 207, 210-11 (1995).

2. See generally, Max Weber on Law in Economy and Society (Max Rheinstein ed., 1954); Trubek, "Max Weber on Law and the Rise of Capitalism," 1972 Wisc. L. Rev. 720 (1972).

3. Max Weber on Law in Economy and Society, supra n. 2 (emphasis in original). See also Max Weber, The Protestant Ethic and the Spirit of Capitalism 25 (Talcott Parsons trans., 1958) ("[M] odern rational capitalism has need, not only of the technical means of production, but of a calculable legal system and of administration in terms of formal rules."). 
ment of markets and hence economic growth." 4 More recently, institutional economics has given new energy to the Rights Hypothesis. A typical formulation can be found in the work of Douglass C. North, who asserts that "impersonal exchange with third-party enforcement ... [ [via an effective judicial system] has been the crucial underpinning of successful modern economies involved in the complex contracting necessary for modern economic growth"5 and that "the inability of societies to develop effective, low-cost enforcement of contracts is the most important source of both historical stagnation and contemporary underdevelopment in the Third World." and others also emphasize the importance of secure property rights: "In response to expropriatory threats of one kind or another, entrepreneurs not only reduce investment, they also invest in less specialized capital (human and physical), which can be moved more easily from one activity to another". ${ }^{7}$ It is probably not unfair, therefore, to sum up the Rights Hypothesis in the words of a recent critic: "productive capitalism needs formal adjudication, judicially enforced contracts, ${ }^{8}$ and inviolable property rights". ${ }^{9}$

4. Trubek, "Toward a Social Theory of Law: An Essay on the Study of Law and Development," 82 Yale L. J. 1 (1982) (criticizing this conception). For a list of representative studies in this vein, see id. at 3, n.7. For a critique and subsequent defense of the law and development movement, see respectively Trubek \& Galanter, "Scholars in Self-Estrangement: Some Reflections on the Crisis in Law and Development Studies in the United States," 1974 Wisc. L. Rev. 1062 (1974) and Burg, "Law and Development: A Review of the Literature and a Critique of 'Scholars in Self-Estrangement'," 25 Am. J. Comp. L. 492 (1977).

5. Douglass C. North, Institutions, Institutional Change and Economic Performance 35 (1990)

6. Id. at 54 .

7. Knack \& Keefer, supra n. 1, at 219 .

8. In this article I generally try use the term "judicial enforcement of contracts" to refer to the enforcement of contract rights through a formal legal system of the kind envisaged in the Rights Hypothesis.

9. Upham, "Speculations on Legal Informality: On Winn's 'Relational Practices and the Marginalization of Law'," 28 Law \& Soc'y Rev. 233, 237 (1994). As Sussman and Yafeh note, "The idea that the protection of property rights is of utmost importance for the economic and financial development of nations has become extremely influential in economics in recent years." Nathan Sussman \& Yishay Yafeh, Constitutions, Commitment, and the Historical Evidence on the Relation between Institutions, Property Rights and Financial Development (January 7, 2003) (unpublished manuscript, on file with author), available at http://papers.ssrn.com/sol3/ papers.cfm?abstract_id=347640.

The literature here is too vast to cite; influential works include North, supra $\mathbf{n} .5$; Weingast, "Constitutions as Governance Structures: The Political Foundations of Secure Markets," $1 \mathrm{~J}$. Inst'l \& Theoretical Econ. 286 (1993); North \& Weingast, "Constitutions and Commitment: The Evolution of Institutions Governing Public Choice in Seventeenth-Century Britain," 49 J. Econ. Hist. 803, 803-32 (1989); La Porta, Lopezde-Silanes, Shleifer \& Vishny, "Legal Determinants of External Finance," 52 J. Fin. 1131 (1997); La Porta, Lopez-de-Silanes, Shleifer \& Vishny, "Law and Finance," 106 J. Pol. Econ. 1113 (1998). 


\section{The Problem}

The history of China's post-Mao economic reform has provided interesting material against which to test the Rights Hypothesis. ${ }^{10}$ Two features of that history in particular stand out for the purposes of this article. First, the institutions by which rights are enforced, in particular courts, are perceived to be weak, and thus rights are perceived to be unenforceable. ${ }^{11}$ (It is perception, which determines whether persons are willing to invest and make deals, that counts for purposes of the Rights Hypothesis. ${ }^{12}$ ) Second, China has indeed enjoyed substantial economic growth in recent years. ${ }^{13}$

There are several ways to interpret these observations together with the Rights Hypothesis. First, the hypothesis could be right and the observation that rights are not enforced wrong, or at least incomplete: rights are necessary for growth to occur, and growth is occurring: although courts don't effectively enforce rights, rights are enforced somewhere else in the system through some other mechanism. There are, of course, various mechanisms for the vindication of claims arising out of contractual relationships that do not involve the court system. For reasons beyond the scope of this article, I believe that it is often inappropriate to think of this as the enforcement of rights as such. ${ }^{14}$ Nevertheless, it is important not to assume that a

10. For a recent qualitative attempt to assess the impact of legal institutions upon economic development in several East Asian countries, see Katharina Pistor \& Philip A. Wellons, The Role of Law and Legal Institutions in Asian Economic Development (1999); see also Ohnesorge, "The Rule of Law, Economic Development, and the Developmental States of Northeast Asia," in Law and Development in East and Southeast Asia 91 (Christoph Antons ed., 2003).

11. For a detailed look at the enforcement powers of Chinese courts, see Clarke, "Power and Politics in the Chinese Court System: The Enforcement of Civil Judgments," 10 Colum. J. Asian L. 1 (1996) and Randall Peerenboom, China's Long March Toward Rule of Law 326-28 (2002).

12. See Johnson, McMillan \& Woodruff, "Courts and Relational Contracts," $18 \mathrm{~J}$. L. Econ. \& Org. 221, 227 (2002) (in the theory of repeated games, "the relevant question is ... what [the entrepreneur] believes would happen if there is a dispute in the future").

13. Both the proposition that China's legal system does not provide strong enforcement of rights and the proposition that China has enjoyed strong economic growth in the era of economic reform will, for reasons of space, be taken for granted in this article and not specifically supported by argument. Obviously, a great deal could be said about both these propositions.

14. For example, it is frequently suggested in the literature that criminal gangs could constitute a kind of informal mechanism for the enforcement of rights when the formal legal system is unable to do so. See, e.g., McMillan \& Woodruff, "Private Order Under Dysfunctional Public Order," 98 Mich. L. Rev. 2421, 2457-58 (2000) (viewing mafia as an element of "private ordering" that arises when legal systems do not function costlessly); Leitzel, Gaddy \& Alexeev, "Mafiosi and Matrioshki: Organized Crime and Russian Reform," 13 Brookings Rev. (Winter 1995), at 26, 28 ("[P]erhaps [the mafia's] main benefit is contract enforcement."); Hay, Shleifer \& Vishny, "Toward a Theory of Legal Reform," 40 Eur. Econ. Rev. 559, 560 (1996) (viewing organized crime as one of several "mechanisms of enforcing agreements and resolving disputes"). This literature fails to consider a crucial distinction between "enforcement" by criminals and enforcement by other informal actors such as peer groups, chambers of commerce, 
mechanism for the enforcement of rights cannot exist simply because it turns out that courts are not that mechanism.

Second, the hypothesis could be right and the observation of growth a misinterpretation of the data: although substantial growth is occurring now, it may be that much more growth would have occurred with a different set of legal institutions, or that the growth we see is a one-time transitional phenomenon that will soon stall out in the absence of legal reform along the lines suggested by the Rights Hypothesis. This interpretation is grounded in the fact that the beginning of the reform era saw numerous unsatisfied market segments, particularly in household goods and services, caused by the standard socialist restrictions on economic activity in these sectors. The relaxation of restrictions meant extraordinary profit opportunities for early entrants - so much so that there was substantial resentment among salaried workers and intellectuals at the hitherto unimaginable sums of money being earned by shoe repairers and hairdressers. Ultimately, however, one would expect additional entrants to compete profits down to normal levels, and indeed the statistics appear to bear out this prediction. ${ }^{15}$ At some point all niches will be filled except those in which success requires security of property rights or effective judicial enforcement of contracts. At this point, if the Rights Hypothesis is correct, growth will taper off.

Third, the hypothesis could simply be wrong: rights aren't protected but significant growth occurs, and therefore there is not an important connection between the two. As David Trubek pointed out thirty years ago, to say, as did Weber, that a market requires a system of effectively enforced rights of property and contract is not the same as saying that economic development requires such a legal system unless we take the further step of positing that the only path to economic development is through the market. ${ }^{16}$ But the history of the Soviet Union and of the People's Republic of China shows that development, at least up to a certain level, can in fact be achieved through planning and without a substantial role for the market. ${ }^{17}$

Moreover, it does seem that a market system can go a considerable distance in the absence of a functioning formal legal system that enforces rights of property and contract. McMillan and Woodruff, for example, document a thriving private sector in Vietnam, even though virtually none of the enterprise managers they interviewed believed

clan elders, and the like: criminals generally make no attempt to ascertain the rights and the wrongs of the dispute, and act on behalf of the party that pays them. Criminals enforce not rights but demands; they do not concern themselves with whether such demands are morally or legally justified.

15. See Barry Naughton, Growing out of the Plan 150-51 (1995).

16. See Trubek, supra n. 4, at 15.

17. See, e.g., Naughton, supra n. 15, at 53 ("[T] have strong growth potential regardless of system. Even before reforms, China's economy was growing at respectable rates."). 
that courts were of any value in dispute resolution. ${ }^{18}$ Certainly it would be difficult to assert that contract rights were better enforced in Vietnam today than in Vietnam under socialism, and it is by no means clear that contracts are better enforced in China today than in China in the Qing dynasty or as far back as the Han two millennia ago, ${ }^{19}$ yet growth rates are surely very different. It may therefore be an overstatement to identify the absence of "effective, low-cost enforcement of contracts" as "the most important source of both historical stagnation and contemporary underdevelopment in the Third World." ${ }^{20}$ Perhaps while having institutions for the low-cost enforcement of contracts is better, all other things being equal, than not having them, the contribution to growth made by such institutions is swamped by the contributions made by other factors.

Equally important and often overlooked is that Weber's formulation, whatever its accuracy, does not strictly speaking require that the legal system provide enforceable rights - that is, the actual ability, in certain special circumstances, to choose to invoke the coercive power of the state in support of one's personal interests. All that is needed is that the system operate in a predictable manner. Therefore, the Rights Hypothesis could be wrong in focusing so strongly on the particular institution of rights. ${ }^{21}$

As can be seen, each of the above interpretations has a certain plausibility. On the other hand, they cannot all be correct. In this article I will attempt to propose an understanding of Chinese legal institutions and their impact on economic transactions (and on investment in particular) that will allow us, if not to reconcile, at least to refine these different interpretations to make them less mutually inconsistent. More broadly, I will propose a reformulation of the Rights Hypothesis that retains the emphasis on security of property but substantially downgrades the importance of a formal legal system that provides effective enforcement of contract rights.

\section{Analysis}

Perhaps the main problem with the Rights Hypothesis is that it is too sweeping and fuses concepts that ought to be kept separate. Its

18. See McMillan \& Woodruff, "Dispute Prevention Without Courts in Vietnam," 15 J. L. Econ. \& Org. 637, 639-41 (1999).

19. On enforcement of contracts in the Qing, see generally Philip C. Huang, Civil Justice in China: Representation and Practice in the Qing (1996) (arguing that the traditional Chinese legal system was more concerned with civil matters than previously believed); on enforcement of contracts in the Han, see Scogin, "Between Heaven and Man: Contract and the State in Han Dynasty China," 63 S. Cal. L. Rev. 1325 (1990) (making a similar argument); see also Scogin, "Civil 'Law' in Traditional China: History and Theory," in Civil Law in Qing and Republican China 35 (Kathryn Bernhardt \& Philip C. Huang eds., 1994).

20. North, supra n. 5 , at 54 (emphasis added).

21. See infra text accompanying nn. 64-67 for further discussion. 
proponents too often forget the difference between a market system in particular and economic development in general, between rights in particular and predictability in general, and between contract rights and property rights. ${ }^{22}$

\section{a. Contract Rights and Property Rights}

Proponents of the Rights Hypothesis assert that the legal systems of developed capitalist economies do two important things: they enforce contractual rights against one's contractual partners, and they provide security for one's property. Thus, if a contract is breached, one gets damages or specific performance, and the government neither confiscates one's property unpredictably nor allows other private parties to do so.

These two things, however, are very different. It is quite possible in principle to imagine a system where there exists no effective machinery for the impartial third-party enforcement of contracts through a formal legal system, but where the government neither engages in unpredictable confiscation of property nor allows others to do so. In such a system, one will not, of course, see any economic activity that requires effective third-party enforcement of contracts through a formal legal system, but one will see activity that merely requires security of property from confiscation.

For what kind of activity is the enforcement of contract rights through a formal legal system the sine qua non? The substantial literature on informal and social sanctions, repeated games, and selfenforcement mechanisms ${ }^{23}$ suggests that in the end there is perhaps only one kind of deal that can never be done without an effective formal legal system: a one-shot deal between strangers who have neither the desire nor the expectation of ever doing business again with the other or with anyone known by the other. In all other kinds of deals, it is possible in principle for another mechanism to provide

22. By "contract rights" I mean roughly the right to have a promisor of equal legal status held to her promise or required to pay damages; by "security of property rights" I mean roughly the probability that one's property will not be confiscated unpredictably by (a) government or (b) other parties that government is unwilling or unable to stop. Predictable confiscation is economically indistinguishable from a tax, and while excessive taxes can of course stifle economic activity, that is not an issue within the scope of this article.

23. See, e.g., Black \& Kraakman, "A Self-Enforcing Model of Corporate Law," 109 Harv. L. Rev. 1911 (1996); Bull, "The Existence of Self-Enforcing Implicit Contracts," 102 Q. J. Econ. 147 (1987); Greif, "Contract Enforceability and Economic Institutions in Early Trade: The Maghribi Traders' Coalition," 83 Am. Econ. Rev. 525 (1993); Telser, "A Theory of Self-Enforcing Agreements," 53 J. Bus. 27 (1980); Winn, "Relational Practices and the Marginalization of Law: Informal Practices of Small Businesses in Taiwan," 28 L. \& Soc. Rev. 193 (1994); and sources cited in North, supra n. 5. 
the needed security and protection from bad faith. ${ }^{24}$ (In the real world, of course, the cost of that other mechanism may be greater than the benefit of the transaction to the parties. ${ }^{25}$ )

In assessing the impact on the economy of the lack of such an effective system for enforcing contract rights, one must therefore ask just how important such one-shot deals (as well as any other deals for which there exists no reasonably effective informal method of sanctioning breaches) are in that economy or to its development. North and others seem to assume that they are common in advanced capitalist economies. This is a question calling for empirical research, ${ }^{26}$ although defining and measuring such transactions is clearly difficult.

24. This might be viewed as an extreme position. I believe it is defensible if the qualifications - particularly the words "never" and "in principle" - are taken seriously.

25. The degree to which informal sanctions can replace formal legal institutions in supporting contractual commitments is much debated. It is generally agreed that where legal institutions are weak, bilateral relationships and other informal institutions can be at least a partial substitute. See Johnson et al., supra n. 12. See also Kathryn Hendley \& Peter Murrell, Which Mechanisms Support the Fulfillment of Sales Agreements? Asking Decision-Makers in Firms (January 23, 2003) (unpublished manuscript, on file with author), available at http://papers.ssrn.com/sol3/papers.cfm?abstract_id=337042 (listing six types of mechanisms on a rough scale of formality, ranging from bilateral relations of personal trust to court action). Some scholars have argued that such relationships can go a very long way, perhaps being a complete substitute for legal institutions. See, e.g., Jones, "Capitalism, Globalization and the Rule of Law: An Alternative Trajectory of Legal Change in China," 3 Soc. \& L. Stud. 195, 213 (June 1994) (discussing role of guanxi (relationships) in China). In a series of articles, however, John McMillan and his colleagues have argued that the scope of transactions beyond the capacity of relational contracts is substantial and important. See, e.g., McMillan \& Woodruff, "The Central Role of Entrepreneurs in Transition Economies," 16 J. Econ. Persp. 153 (Summer 2002) (describing the types of transactions for which relational contracting is inadequate) [hereinafter McMillan \& Woodruff, The Central Role of Entrepreneurs]; McMillan \& Woodruff, supra n. 18, at 63) (same). Even weak courts can play an important role in facilitating economic activity; ease of entry, for example, has been critical to economic success in transition economies, see McMillan \& Woodruff, The Central Role of Entrepreneurs, supra, and entrepreneurs in transition economies who believe that courts are effective offer more trade credit and are more willing to take on new trading partners, thus lowering barriers to entry, see Johnson et al., supra n. 12. Raja Kali has also written in a similar vein, arguing that while networks of relationships can arise in response to inadequate legal institutions and even do a good job in replacing them, their negative effects on non-members could outweigh their beneficial effects on members, and thus, from an economy-wide standpoint, reduce overall economic efficiency. See Kali, "Business Networks in Transition Economies: Norms, Contracts, and Legal Institutions," in Assessing the Value of Law in Transition Economies 211-28 (Peter Murrell ed., 2001).

None of this, of course, solves the problem of how governments with limited resources should spend their money in societies at a particular level of economic development. Strengthening courts in order to protect contract rights will apparently do something, but putting the same resources into building other kinds of institutions or preventing certain kinds of behavior - might do more.

26. See, for example, Macauley, "Non-Contractual Relations in Business: A Preliminary Study," $28 \mathrm{Am}$. Soc. Rev. 55 (1963), in which one-shot relationships between strangers were conspicuously absent in the business community under study. 
Turning now to property rights, for what kind of economic activity is freedom from fear of arbitrary confiscation by government (or by those whom government allows to act) the sine qua non? The answer is clear: just about any kind of investment other than investments with the very shortest of time horizons. In other words, the greater the fear of arbitrary confiscation, the shorter will be the time horizon of any investments. This means that a whole class of economically rational investments - those with a large payoff, but one which is delayed or stretched out over several years - will not get made.

In sum, my minimum claim is that the enforcement or lack thereof of contract rights and the security of property rights can involve very different consequences and ought to be conceptually distinguished. My stronger claim is that whether contract rights are judicially enforced is less important than whether property rights are secure: the lack of an effective formal judicial system that enforces contract rights puts definitely out of reach only a relatively small number of growth-enhancing transactions, whereas the fear of confiscation of one's property by government makes a very large number of growth-enhancing investments impossible.

\section{b. The Idea of Rights vs. the Idea of Predictability}

Suppose we grant the claim of the Rights Hypothesis that, all other things being equal, it is more conducive to economic development to have predictability than not to have it. Clearly, predictability has economic value; businesspeople often spend money, for example, to see if people are likely to buy a product before they invest in the factory needed to make it. More important to the Rights Hypothesis, however, is the claim that economic development is furthered by predictability in certain specific areas: the enforcement of contract rights and the security of property rights.

Where the Rights Hypothesis again goes too far, however, is in failing to distinguish between predictability and rights. Just as investment in agriculture depends on predictability about matters respecting which the farmer has no legal rights - for example, that spring will follow winter, or that seeds, if watered and fertilized, will grow - so we can imagine a legal system that contains no rights but that operates in a predictable manner. A system composed entirely of reglementation - defined by Weber as "those norms which only embody instructions to state officials as regards their duties, but, in contradistinction to what may be called 'claim norms,' do not establish any 'rights' of individuals" 27 - could in principle provide sufficient stability of expectations to support a reasonably well

27. Max Weber on Law in Economy and Society, supra n. 2, at 42. 
functioning market. ${ }^{28}$ Thus, it is a mistake to look solely at institutions that support rights - such as courts - to see if stability of expectations can exist. One must look at all the government agencies that adjust relations between parties and have the power to order the transfer of resources from one party to another.

\section{c. Reformulating the Rights Hypothesis}

The analysis above suggests that there are some serious internal problems to the Rights Hypothesis in its standard form, to say nothing of the problems created by evidence that appears to contradict it. This section of the article examines the arguments and evidence in favor of the proposition that a reasonable assurance to would-be investors that the fruits of their investment will not be confiscated unpredictably is far more important to economic development than a formal legal system that enforces contract rights.

Douglass C. North is one of the foremost proponents of the Rights Hypothesis in its full form: that is, the claim that enforcement of contract rights and security of property rights are both necessary to economic development. ${ }^{29}$ If one looks closely, however, at North's illustrative examples of the institutions and practices that enabled England on the one hand to grow and prosper and caused Spain on the other to stagnate, one finds that he never, except in the most abstract way, cites the predictable enforcement of contract rights. Instead, he cites examples of greater or lesser security of property against government depredation. The bad old days of the Stuarts, for example, saw "repeated fiscal crises . . . that led them to engage in forced loans, to sell monopolies, and to engage in a variety of practices (including wealth confiscation) that rendered property rights less secure." 30 North sees the Glorious Revolution as an attempt, among other things, "to solve the problem of controlling the Crown's exercise of arbitrary and confiscatory power." 31 The success of this attempt led, in North's view, to a rapid development of capital markets and access by the government to an unprecedented level of funds, because lenders had "a clear perception that the government would honor its agreements." 32 North concludes that

[t]he security of property rights and the development of the public and private capital market were instrumental factors

28. As Weber further remarked, "[P]rivate interests enjoy protection, not as guaranteed rights, but only as the obverse aspect of the effectiveness of these regulations." Id. at 44. In other words, if the regulations are effective, private interests can be protected in the absence of any system of rights.

29. See, for example, North, supra n. 5, and Douglass C. North \& Robert P. Thomas, The Rise of the Western World (1973).

30. North, supra n. 5, at 139.

31. Id.

32. Id. 
not only in England's subsequent rapid economic development, but in its political hegemony and ultimate dominance of the world. ${ }^{33}$

When he looks at Spain and the reasons for its decline in the 17 th century from the mightiest empire in the West since Rome to the status of second-rate power, North tells a story of "the expulsion of Moors and Jews, rent ceilings on land and price ceilings on wheat, [and] confiscations of silver remittances to merchants in Seville" as disincentives to productive activity. ${ }^{34}$ In The Rise of the Western World, North and his co-author also note the disincentives to agricultural investment in Spain occasioned by the Crown's grant to the sheepherders' guild of the right to run sheep over agricultural land owned by others. ${ }^{35}$

What all these examples have in common is that they essentially involve the government either keeping a promise to preserve the expected value of an asset or else not allowing others to deprive one of the expected value of an asset. ${ }^{36}$ They simply do not show anything one way of the other about the need for enforcement of laws of property and contract against third parties with whom one deals.

A similar emphasis on freedom from arbitrary and unpredictable confiscation can be found in a study by Stephen Knack and Philip Keefer, ${ }^{37}$ an often-cited effort to test the Rights Hypothesis empiri-

33. Id. Recent work by Sussman and Yafeh has questioned the empirical premises of the claim that Britain's supremacy stemmed from institutions that secured property rights and thereby lowered the cost of borrowing both to the government and to private investors. They show that after the institutional changes pointed to by North, supra n. 5, and North \& Weingast, supra n. 9, interest rates remained high, and the volume of British government debt low, for nearly a century. See Sussman \& Yafeh, supra n. 9. The same authors make similar findings with respect to Japan in the Meiji period. See Sussman \& Yafeh, "Institutions, Reforms, and Country Risk: Lessons from Japanese Government Debt in the Meiji Period," 60 J. Econ. Hist. 442 (2000) (finding that institutional change, reforms, a constitution and other similar factors had little impact on the interest rate on bonds issued by the Japanese government between 1870 and 1914). See also Stasavage, "Credible Commitment in Early Modern Europe: North and Weingast Revisited," 18 J. L. Econ. \& Org. 155 (2002) (also casting doubt on specific empirical premises).

34. See North, supra n. 5, at 115

35. See North \& Thomas, supra n. 29, at 4.

36. In buying a house, writes North,

the discount from the frictionless exchange envisaged in economic theory will be greater to the degree that the institutional structure allows third parties to influence the value of the attributes that are in the utility function of the buyer. These could include the behavior of neighbors, the likelihood of theft, and the possibility of changes by local authorities in zoning ordinances that may affect the value of the property. The greater the uncertainty of the buyer, the lower the value of the asset. It is worth emphasizing that the uncertainties described above with respect to the security of rights are a critical distinction between the relatively efficient markets of high income countries today and economies in the past as well as those in the Third World today.

North, supra n. 5, at 63.

37. See Knack \& Keefer, supra n. 1. 
cally. While the authors state or imply at several points in their study that what they are testing is the importance of rights of both property and contract to economic growth, an examination of their methodology shows that in fact contract enforceability, even if measurable and measured accurately, has little or no part in the indices with which they correlate economic growth and private investment.

Knack and Keefer use two indices, both based on indicators compiled by private international investment risk consultants, that they believe measure directly the dimensions of property rights emphasized by North and others. The first of these indices is derived from the International Country Risk Guide (ICRG) ${ }^{38}$ and is the aggregate of five variables measuring expropriation risk, rule of law, repudiation of contracts by government, corruption in government, and quality of bureaucracy. The second index is derived from Business Environment Risk Intelligence (BERI) ${ }^{39}$ and is the aggregate of four variables measuring contract enforceability, infrastructure quality, nationalization potential, and bureaucratic delays. They find that both the ICRG and the BERI indices outperform other indices of property and contract rights used in previous studies, ${ }^{40}$ and that while the ICRG index explains growth best, the BERI index explains private investment best.

What the authors do not do is to attempt seriously to distinguish property rights from contract rights - i.e., the security of an expectation that one will not be subject to arbitrary and unpredictable confiscation as opposed to the security of an expectation that one will be able to enforce a promise made by another with whom one does business. They attempt to tie unreliability of government promises to unreliability of all third-party promises with the assertion that "[i]t is likely that if private actors cannot count on the government to respect the contracts it has with them, they will also not be able to count on the government enforcing contracts between two private parties," 41 but this assertion rests on only a superficial symmetry and is not convincing. While the ICRG and BERI indices both present plausible measures of security against unpredictable expropriation, the ICRG contains no measures of contract enforceability and only

38. For further information on this source, including a description of the methodology, see PRS Group, International Country Risk Guide, at http://www.prsgroup. com/icrg/icrg.html.

39. For further information on this source, see Business Environment Risk Intelligence, at http://www.beri.com.

40. These other indices did not purport to measure property and contract rights directly, but instead used measures of political violence or political freedoms and civil liberties in the belief that these measures could be a suitable proxy for the absence or presence of secure property and contract rights. See, e.g., Barro, "Economic Growth in a Cross Section of Countries," 106 Q. J. Econ. 407 (1991) (using measures of political violence) and Gerald W. Scully, "The Institutional Framework and Economic Development," $96 \mathrm{~J}$. Pol. Econ. 652 (1988) (using measures of civil liberties).

41. See Knack \& Keefer, supra n. 1, at 210. 
one of the four BERI variables attempts to do so. Consequently, while the Knack and Keefer study supports the Rights Hypothesis with respect to security of property rights, it simply does not address the importance of contract rights. Furthermore, security of property rights - at least as discussed by North and as measured by Knack and Keefer - has little to do with formal legal institutions. It is much more a question of political institutions. ${ }^{42}$

Other studies, whatever their conclusions, in fact share the emphasis on security of property. A recent study by Rodrik and his colleagues, for example, examines the respective contributions of geography, institutions, and openness to trade to wealth levels around the world, and concludes that the quality of institutions trumps everything else. The institutional environment, however, is measured by "observers' views as to the likelihood that investors will retain the fruits of their investments, the chances that the state will expropriate them, or that the legal system will protect their property rights." 43

In short, while the Rights Hypothesis is generally stated in terms of a formal legal system that protects rights of property and contract, the qualitative and quantitative work that purports to support the hypothesis tends to focus almost exclusively on security from arbitrary expropriation, without being concerned about whether that security comes from a well functioning legal system or simply a wise government that prudently declines to exercise the power it has to expropriate in order to maximize its ultimate revenue from taxing the income stream. Contract rights are simply not addressed at all.

\section{d. The China Problem}

We can now return to the issue raised at the beginning of Section 2: what are the implications of the evidence from China for the Rights Hypothesis as reformulated to stress freedom from fear of confiscation?

Imagine two plots of land side by side in the Chinese countryside. On one sits a typical TVE ${ }^{44}$ making buttons. On the other toils a

42. See Weingast, supra n. 9 , at 286.

43. Rodrik, Subramanian \& Trebbi, "Institutions Rule: The Primacy of Institutions Over Geography and Integration in Economic Development," (Nat'l Bureau of Econ. Research, Working Paper No. W9305, 2002), available at http://www.nber.org/ papers/w9305. For another study in this vein, see Acemoglu, Johnson, \& Robinson, "The Colonial Origins of Comparative Development: An Empirical Investigation," 91 Am. Econ. Rev. 1369 (2001) (using an index of protection against expropriation).

44. TVE is the general term used for township and village enterprises: businesses that are typically founded and run by local government. Technically they belong to the collective sector, as opposed to the private sector or the state sector, and are therefore said to be "owned" by the citizenry of a particular locality. This ownership is for all intents and purposes meaningless even as a formality; all the important indices of ownership rest with local government. Naughton, "Chinese Institutional Innovation 
farmer. Both the factory and the farmer carry on their business under the same local government. If they have a contract dispute, the same court system will hear (or refuse to hear) their case. In short, from the standpoint of the ability of the formal legal system to protect their contract rights, they are similarly situated. Yet it is very likely that the TVE fits the general national pattern of solid growth in investment and output in its sector, ${ }^{45}$ while the farmer fits the pattern of slow growth in agriculture relative to the remarkable growth of the early 1980 s. $^{46}$ Why might this be so?

and Privatization from Below," 84 Am. Econ. Rev. 266, 267 (1994). Indeed, TVEs have been plausibly characterized as similar to subsidiaries of the township, viewed itself as a diversified corporation. See Oi, "Fiscal Reform and the Economic Foundations of Local State Corporatism in China," 45 World Pol. 99 (1992); Nee, "Organizational Dynamics of Market Transition: Hybrid Forms, Property Rights, and Mixed Economy in China," 37 Admin. Sci. Q. 1 (1992).

Although it is important in understanding TVEs to know that they are run by and for government bodies, not private investors, it is equally important to understand that these government bodies in many cases wish to maximize profits and operate in a competitive market environment. Most importantly, unlike state-owned enterprises, TVEs have no hope of central government support if they run into trouble, and their workers, unlike SOE workers, have no implicit guarantee or expectation of employment. Thus, they face a hard budget constraint. For a contrary but distinctly minority view, holding that "money-losing TVEs typically stay in business, despite their inability to repay debts," see Wang, "Capital Formation and Utilization," in China's Rural Industry: Structure, Development, and Reform 225 (William Byrd and Q. Lin eds., 1990). This is hard to reconcile with the finding of Weitzman and Xu that in 1989 alone, a full sixth of TVEs, some three million, went bankrupt or were taken over by other TVEs, although the term "taken over" may in fact conceal a bailout. See Weitzman \& Xu, "Chinese Township-Village Enterprises as Vaguely Defined Cooperatives," $18 \mathrm{~J}$. Comp. Econ. 121, 135-36 (1994) (citing Chinese statistical sources). A concise and insightful summary of relevant TVE characteristics can be found in Jin \& Qian, "Public vs. Private Ownership of Firms: Evidence from Rural China," 113 Q. J. Econ. 773, 776-79 (1998).

45. Available statistics show a steady rise over the ten-year period from 1990 through 1999 in a number of relevant indices of TVE activity: fixed investment, circulating funds, profits, business revenues, and value added. Employment, however, has remained steady since 1993, and the total number of TVEs has decreased from a peak of about 25 million in 1994 to about 21 million in 1999. Zhongguo Xiang-Zhen Qiye Nianjian 2000 [China Township and Village Enterprise Yearbook 2000], 15-18 (2000). See also Wang \& Kalirajan, "On Explaining China's Rural Sectors' Productivity Growth," 19 Econ. Modelling 261 (2002); Nongye Bu Xiangzhen Qiye Ju Xinxi Tongji Chu [Ministry of Agriculture, Township and Village Enterprise Bureau, Information and Statistics Office], "2001 Niandu Quanguo Xiangzhen Qiye Fazhan Tongji Gongbao" [Statistical Report on the Development of Township and Village Enterprises Nationwide in 2001], Zhongguo Xiang-Zhen Qiye Kuaji [Chinese Township and Village Enterprise Accounting], No. 6 (2002), at 4-7.

46. See generally Li, Rozelle \& Brandt, "Tenure, Land Rights, and Farmer Investment Incentive in China," 19 Ag. Econ. 63 (1998). Between 1955 and 1980, when reforms began spreading in earnest, the annual per-person increase in grain production was 1.3 kilograms. From 1980 to 1984 , that figure rose to 16.2 kilograms. Between 1984 and 1993, the figure fell to 2.9 kilograms even though agricultural policies had, if anything, become more liberal than before. See Prosterman, Hanstad \& Li, "Can China Feed Itself?," Sci. Am. (November 1996), at 90. The explanation appears to be strongly connected with the move from collective farming to family farming. At the beginning of 1980, $1 \%$ of rural households had made this shift. By the end of 1984, 99\% of rural households had. Lin, "Rural Reforms and Agricultural Growth in 
It would be foolhardy, of course, to attempt a single-factor explanation of what is undoubtedly a complex phenomenon. First, the TVE and the farmer are not identically situated with respect to the ability of the formal legal system to enforce their contract rights. The TVE is a bigger actor and has more resources and clout in the community than a single farmer. Second, the TVE, again because it is bigger and has more resources and clout, is better situated than the farmer to take advantage of other mechanisms that might substitute for enforcement of contract rights through the formal legal system - mechanisms ranging from gathering information about the trustworthiness of prospective contractual partners to hiring thugs to collect on contract debts. ${ }^{47}$ But these explanations do not really contradict, and in fact can be viewed as supporting, the reformulated Rights Hypothesis, which downgrades the importance of a formal legal system that can enforce contract rights between strangers.

From the standpoint of incentives for investment, it may simply be that all the large returns that can be obtained from investment in agriculture at China's current technological level have already been achieved, whereas light industry is still far from this point. But empirical research seems to suggest that there is in fact room for significant further returns from agricultural investment:

Many agricultural scientists in China have concluded that farmers could obtain crops two to three times larger than what they currently harvest. The farmers we talked to also acknowledged that the land could afford much larger yields. Yet few of them had made any major alterations to their plots, even though they all knew that such changes would boost their output. ${ }^{48}$

Why are these investments not being made?

The farmers' reluctance to sink money and labor into any extensive modifications can be directly attributed to their underlying fear that they may not be able to hold on to their property long enough to realize a return on their investment. (In contrast to the changes already made, the costs of which were recovered quickly, the next phase of improvements will take many years to pay for themselves.) Back in 1984 the central government ordered that land con-

China," $82 \mathrm{Am}$. Econ. Rev. 34, 38 (1992). Once the shift was complete, apparently, there were no more gains to be had from it.

47. For a good review of various theories of TVE advantages as well as an attempt to generate and test hypotheses from them, see Jin \& Qian, supra n. 44. There has been some debate on whether TVEs are in fact efficient; for a review, see Whiting, "Contract Incentives and Market Discipline in China's Rural Industrial Sector," in Reforming Asian Socialism: The Growth of Market Institutions 65-67 (John McMillan \& Barry Naughton eds., 1996).

48. Prosterman et al., supra n. 46 , at 93. 
tracts be extended for 15 years, but local officials have not implemented this policy to any significant degree. Indeed, very few farmers even possess written contracts granting them the right to tend a specific plot. And when they do obtain a contract, the expiration date is often left blank, or the term may change without warning, or the contract may be terminated far short of what was originally promised. ${ }^{49}$

This analysis is reinforced by a survey study conducted by $\mathrm{Li}$, Rozelle, and Brandt, ${ }^{50}$ which found a strong and robust connection between the right to use land for long (or indefinite) periods of time and the making of land-saving investments, although they did not conclude that the lack of such rights carried a high efficiency cost. ${ }^{51}$

49. Id. Note that the contract spoken of here is not an ordinary commercial contract with another party of equal legal status, but a contract with the local government for long-term land tenure. Thus, a violation of that contract by the local government in redistributing the land is more appropriately viewed as a problem of security of property against government confiscation than as one of enforcement of contract rights in business dealings.

50. Li et al., supra n. 46.

51. It should be noted that the diagnosis of Prosterman et al., supra $n$. 46, is not unchallenged. James Kung and Shouying Liu review the literature on the relationship between tenure security and agricultural productivity, and question this diagnosis on the basis of survey results showing that farmers did not have a strong preference for private ownership and that a majority reported that they preferred the existing system of periodic land redistribution to account for changes in family size. Kung \& Liu, "Farmers' Preferences Regarding Ownership and Land Tenure in PostMao China: Unexpected Evidence from Eight Counties," 38 China J. 33 (1997). The key flaw in the authors' argument, however, is that a preference by farmers for a particular system is by no means equivalent to a refutation of the proposition that that system contains severe disincentives to agricultural investment. A detailed discussion of their findings is, however, beyond the scope of this article.

Other studies have explored the link between security of tenure and fertilizing practices specifically. Li et al., supra n. 46 , do find a link, but only a small one. Kung and Cai state that "[w]hile the [popularly] postulated negative relationship between ill-defined property rights in land and suboptimal fertilizing practices is an intuitively plausible hypothesis, it is not adequately supported by empirical evidence." Kung \& Cai, "Property Rights and Fertilizing Practices in Rural China: Evidence from Northern Jiangsu," 26 Mod. China 276 (2000). There are several difficulties, however, with the argument of Kung and Cai. First, the conventional wisdom they set out to refute is the claim that ill-defined property rights in land lead to sub-optimal fertilizing practices and other inefficient uses of land. But what they show is that non-private property rights do not necessarily give rise to tenure insecurity. This is not the same thing; non-private property rights need not be ill-defined, and tenure insecurity is of course a different thing from sub-optimal fertilizing practices. Second, they show that land tenure was not in fact as unpredictable in the villages they studied as has been assumed; reallocations of land within the villages they studied were frequently announced well ahead of time, so that farmers could adjust their input investments. Third, they found some anecdotal evidence of informal mechanisms (the exclusion from reallocation of families that had not taken proper care of their land) operating to ensure that all families made appropriate input investments. Thus, farmers had an incentive to take proper care of their land and some assurance that land they received upon reallocation would have been equally well cared for.

The differing conclusions of various studies may be the result in part of the wide variation across the country in land tenure regimes, despite the ostensible primacy of central government policy. See Brandt, Rozelle, Huang \& Li, "Land Rights in China: 
While agricultural growth has slowed considerably, growth in the TVE sector continues steadily. Apparently TVEs (or more precisely, the investors and managers of TVEs) do not have the same fear of confiscation of the fruits of their investment that farmers have. If indeed this is part of the explanation, it makes sense, for a key feature distinguishing TVEs from farmers is that TVEs are the creatures of local government, precisely the same body that farmers fear will confiscate or redistribute their land. While farmers, therefore, may face uncertainty as to the results of long-term investments such as well-digging or the terracing of fields, TVEs, whatever their other problems, face no real uncertainty in this area at all. Provided the economics are right, the only concern of the investor (local government) is the unlikely one that several years down the road the central government might confiscate all or part of its treasury. ${ }^{52}$

Whether TVEs do indeed enjoy a unique security of expectations in investment is controversial. A substantial body of literature exists asserting that the Rights Hypothesis, even when limited to property rights, is refuted by the success of TVEs in what is claimed to be an environment of vague and insecure property rights. As will be shown below, I believe that this literature places undue emphasis on formal instead of realistic categories of ownership and therefore does not succeed in its challenge to the property rights element of the Rights Hypothesis.

Weitzman and $\mathrm{Xu}$, for example, noting correctly the hollowness of the formal ownership rights of "the community," go on to conclude that TVEs have "no owner in the spirit of traditional property rights theory." 53 They reject the local government as a candidate for the role of owner on the grounds that it lacks several elements of full control: it is restrained from firing workers who are community residents, for

Fact, Fiction, and Issues," 47 China J. 67 (2002) (finding that in a sample of 31 villages in northeast China, land resources were organized in almost 20 different ways). Another contributing factor may simply be inconsistent terminology. Rozelle and his colleagues, for example, cite approvingly a Chinese study that "found almost no evidence of expropriations of investments in the land in rural China during the last 10 years." Rozelle, Huang, \& Zhang, "Emerging Markets, Evolving Institutions, and the New Opportunities for Growth in China's Rural Economy," 13 China Econ. Rev. 345, 350 (2002). Another article published in the same year, however, and sharing two coauthors with the first, states (a) that more than half of all cultivated land in a broad sample of villages surveyed in 1996 had been reallocated at least once, and (b) that households are typically not compensated for investments they have made in land when it is reallocated. See Brandt et al., supra. A taking without compensation is expropriation. The Chinese study cited may have been using a narrow legal definition of expropriation, and not an economic one.

52. Even this concern may not have a substantial effect on investment patterns, since all alternative investments will carry the same risk. The only way open to local government leaders for the certain avoidance of confiscation is to consume government funds now through the familiar rituals of banqueting and travel at public expense.

53. Weitzman \& Xu, supra n. 44 , at 132 . 
example, and "has to take into account ... the preferences of residents" in its decision making respecting the establishment of TVEs. ${ }^{54}$ This hardly disqualifies local government as owner. If a private entrepreneur faced statutory limits on her ability to discharge workers, we would not conclude that she was for that reason not a true owner. With respect to taking into account the views of residents, a decision to establish a TVE is hardly the same as the continuing series of decisions involved in running one, and in any case Weitzman and Xu fail to distinguish between what the local government must do and what it would be wise to do as a matter of policy. There is no question that the local government could, if it wished, set up a TVE without popular approval, in the same way that it can levy taxes and fees without popular approval.

Because they reject the notion that local government is an owner with clear rights of management, usufruct, and disposition over the assets of the TVE, they find TVE success a puzzle, and resort to a concept of cultural propensity to cooperate (lamda) in order to resolve it. They assert that conventional property rights theory assumes a low-lamda culture in which clearly defined property rights are needed to prevent shirking and opportunistic behavior. Perhaps China's TVEs are able to succeed, they hypothesize, because they exist in a high-lamda culture where formal rights and binding legal rules are less important.

The problem with lamda as an explanatory variable is that it turns out not to explain anything. Weitzman and Xu use it to account for different outcomes (e.g., differential rates of success for firms with a TVE structure) when all other factors are held equal. The question, however, is what these "other factors" are. If they turn out to be everything that we can think of that might be relevant to TVE success, then lamda is by definition simply a residual category for things we cannot think of. In other words, lamda is just a label for things we cannot explain. But there is no particular reason to equate the unexplained with "culture." Given that lamda is a residual category, one would expect it to get smaller and less important the more we learn about identifiable factors contributing to TVE success.

The claim of unclear property rights is repeated by David $\mathrm{Li}$ in another frequently-cited article:

$[\mathrm{N}]$ o one can claim that the Chinese non-state sector enjoys clearly defined property rights. Most of the non-state firms are collectives and other kinds of non-private firms. The owners of these collective firms are often loosely specified, e.g., all residents in a community. ${ }^{55}$

54. Id. at 134 .

55. Li, "A Theory of Ambiguous Property Rights in the Transition Economies: The Case of the Chinese Non-State Sector," 23 J. Comp. Econ. 1, 2 (1996). 
$\mathrm{Li}$ then develops a theory to explain why ambiguity and vagueness could actually be advantageous. The analysis is flawed, however, by its origin in the notion that there is any vagueness about ownership of a TVE. While the category of "all residents in a community" is indeed vague, and while one can certainly find various pronouncements to the effect that the owners of a TVE are "all residents in a community," this ownership is no more meaningful than the "ownership" interest of French citizens in Air France and deserves equal attention - that is to say, none - in a legal or economic analysis. Thus, one can indeed claim that property rights in the non-state sector are, at least sometimes, clear:

Local residents possess no "right of membership" in TVEs, nor do TVE workers possess any rights to participate in TVE management. In most cases that have been studied, township and village officials in their official capacity possess all the key components of property rights: control of residual income; the right to dispose of assets; and the right to appoint and dismiss managers and assume direct control if necessary. ${ }^{56}$

Other scholars whose analysis is distracted by the perceived need to take into account somehow the ownership rights of "the community" or "local citizens" (as opposed to the local government) include Chang and Wang, ${ }^{57}$ Che and Qian, ${ }^{58}$ and Hong. ${ }^{59}$

56. Naughton, supra n. 44 , at 267.

57. See Chang \& Wang, "The Nature of the Township-Village Enterprise," $19 \mathrm{~J}$. Comp. Econ. 434, 447 (1994). The authors argue that TVEs are afflicted by a problem of separation of ownership from control that stems from ownership by citizens combined with management by the local government. But this is to get caught up in formalisms. De facto ownership is in the hands of local government. The separation of ownership from control occurs because the local government, as an abstract entity, can act only through human agents such as government officials. Yet another layer of agency is created when those officials in turn appoint others to manage the TVE. In any case, the principal-agent problem is no different from that faced by state-owned enterprises (SOEs) or large private enterprises in market economies:

The problem is that the state as the owner was unable to manage each enterprise by its own, and needed to appoint managers to do it. Similar principalagent conflict within large private enterprises also exists in market economies. In other words, the ownership and management of SOEs have always been separated. The managers of SOEs were appointed or recruited by the state.

Lin, Cai \& Li, "Creating an Environment for Fair Competition Is the Core of Enterprise Reform," in The Reformability of China's State Sector 47, 55 (Guanzhong James Wen \& Dianqing Xu eds., 1997).

58. See Che \& Qian, "Institutional Environment, Community Government, and Corporate Governance: Understanding China's Township-Village Enterprises," $14 \mathrm{~J}$. L. Econ. \& Org. 1 (1998). The authors analogize the township to a multidivisional firm, with each TVE as a division within the firm, the local government as the board of directors, and local citizens as stockholders. While the analogy of the TVE to a division within a multidivisional firm is well taken, the notion of local citizens as equivalent to stockholders is difficult to accept. Among other things, they have no vote in "firm" management and they have no identifiable, protected, and transferable right 
If, as I argue, ownership rights over TVEs and their cash flow are not significantly ambiguous or vague, then a critical distinction between a TVE run by local government and a privately-run enterprise is that the TVE does not need to fear arbitrary expropriation, either direct or indirect through oppressive taxes and fees. ${ }^{60}$

The threat of arbitrary expropriation in China today does not come from the central government; it comes from local government. ${ }^{61}$ It is local government that is the most closely acquainted with a firm's financial health and that has the greatest incentive and ability to loot it. A firm owned by local government is obviously not subject to this uncertainty, since the local government internalizes the cost of whatever decision it makes about distribution of TVE profits. Local government investment in an enterprise, then, is (unlike local private investment) absolutely undeterred by the worry that the investor cannot fully capture the return on the investment. With respect to superior levels of government, it appears that the property rights of local levels of government are quite robust. ${ }^{62}$ Superior levels of government do not in general take from inferior levels without compensation.

With this security against expropriation, local governments not only can invest more than private entrepreneurs, but they can invest more efficiently. As Knack and Keefer point out, an investor concerned about expropriation is likely to invest in less specialized capital (human and physical) that can be moved more easily from one activity to another. ${ }^{63}$ Not only does this have static efficiency effects, but it also discourages dynamic gains from innovation, since such innovation in more likely to thrive where there is specialization.

The Chinese example also sheds some interesting light on the question of whether economic development actually requires rights or simply predictability. While China's legal system does not seem to protect the former very well, it may offer a reasonable degree of the latter.

A good deal of discussion of the Chinese legal system is in terms of what it lacks: there is a lack of enforcement, a lack of legal con-

to any of the wealth created by the "firm". Simply being in a position to benefit from local government expenditure if one still resides in the area when the expenditure is made is not enough to support this analogy in a meaningful way.

59. See Hong, "The Shareholding Cooperative System and Property Rights Reform of China's Collective Township-Village Enterprise," 23 Asian Profile 359 (1995).

60. For an attempt to assess the importance of various differences, see Jin \& Qian, supra n. 44.

61. For this reason, I do not find convincing the claim of Chang and Wang that local citizens are designated as formal owners of TVEs in order to make credible a commitment by the central government not to expropriate. See Chang \& Wang, supra n. 57 , at 447 .

62. See generally David Granick, Chinese State Enterprises: A Regional Property Rights Analysis (1990) and Naughton, supra n. 15, at 43.

63. See Knack \& Keefer, supra n. 1, at 219. 
sciousness, a lack of trained judges. ${ }^{64}$ All this is true, and indeed in many cases these lacks are seen as deficiencies by Chinese legal scholars and others working in the system. In part because the institutions of the Chinese legal system come with labels that are customarily translated using familiar English words - "courts", "judges", "laws", etc. - without much thought about whether such words are really appropriate, pointing out the ways in which the Chinese system is not in fact like the system in which we use these terms is a necessary part of understanding that system. But it is far from sufficient. The Chinese legal system itself, like the society of which it is a part, does not function on the basis of what it lacks; it functions on the basis of what it has. Because the Rights Hypothesis is essentially oriented to the would-be investor's ability to predict what will happen to the investment, the question should be not whether China possesses or lacks courts that enforce rights, but simply whether investors and others engaged in business in China have adequate predictability for their needs.

To the extent the legal system has anything to contribute to this, China's - or any other country's - system is not any the less capable in principle of doing so simply because it consists largely of Weberian "reglementation" and not "claim norms". ${ }^{65}$ Further inquiry, therefore, would be more usefully focused on the question of predictability than on the presence or absence of enforceable legal rights. ${ }^{6} 6$

The inquiry into predictability must also ask: predictability for whom? Proponents of the Rights Hypothesis typically assume that there must be predictability for private economic actors, because they assume that economic development requires a market and that a market requires private actors. Putting aside the question of whether or not economic development in fact requires a market, it does not appear to be true that a market requires private actors. What it does generally require in order to have meaningful bargaining over prices is actors that are trying to buy low and sell high. The Chinese case certainly demonstrates that governmental actors such as TVEs are

64. I confess to engaging in this kind of discussion myself. See Clarke, supra $n$. 11. I am grateful to Ellen Hertz for discussions regarding the problems with this approach.

65. This characterization of the Chinese legal system raises more issues than can be dealt with adequately in a mere footnote. I discuss these issues more fully in Clarke, "Justice and the Legal System," in China in the 1990s (Robert Benewick \& Paul Wingrove eds., 1995). See also Thomas B. Stephens, Order and Discipline in China (1992).

66. As Albert Chen points out, modern critical social and legal theory, while by no means denying that Western societies have seen significant economic development, does deny that law in Western societies is autonomous, rational, and determinate, and therefore challenges the central causal claim of the Rights Hypothesis. See Chen, "Rational Law, Economic Development and the Case of China," 8 Soc. \& L. Stud. 97 (1999). Critical theory does not, however, deny that there is predictability in societies; it just denies that it comes from an autonomous legal system and a regime of rights. 
capable of fulfilling this role and that a market can flourish in the absence of significant true private actors. ${ }^{67}$ Therefore, even if it could be shown that private actors do not enjoy the benefits of predictability in contract and property, that need not be fatal to economic growth. We might find at the same time that non-private actors do have predictability and can create flourishing markets and economic growth.

\section{Conclusion}

One of the reasons why proponents of the Rights Hypothesis have so often lumped security of property together with enforcement of contract rights may be that societies characterized by security of property from arbitrary government confiscation also tend to be characterized by the relatively effective enforcement of contract rights. Thus, they have mistaken effect for cause. China presents an invaluable case study for the hypothesis because although it seems that rights of any kind are not well protected through courts and the legal system, economic growth does take place, and it seems to take place in those sectors that are free of the fear of arbitrary government confiscation. Such sectors can exist in China in a way they cannot in other developing countries because of the near absence of a true private sector in industry and the dominant role played by governmental bodies - however much they may be forced to play by the rules of the market - as economic actors.

The reformulation of the Rights Hypothesis presented here may also offer a solution to Max Weber's "England problem." 68 Weber believed that "the degree of legal rationality [in England] is essentially lower than, and of a type different from, that of continental Europe." 69 Yet he could not avoid observing the strength in England of precisely the kind of capitalism for which he had posited the necessity of legal rationality. It may be, of course, that Weber simply defined too narrowly the type of legal rationality truly necessary. On the other hand, it is worth pointing out what England did have in common with the successful capitalist countries of Western Europe, a feature tirelessly pointed out by North: a government that made cred-

67. As numerous scholars have pointed out, the key difference between TVEs and state-owned enterprises is that TVEs face a much harder budget constraint. See, e.g., Che \& Qian, supra n. 58, at 3; Jin \& Qian, supra n. 44; Li, "The Institutional Foundation of Self-Enforcing Contracts: The Township Enterprise" (unpublished manuscript, on file with author) (1997). But see Edward Steinfeld, Forging Reform in China: The Fate of State-Owned Industry 239-40 (1998), who asserts that as TVEs become large and successful, they may be able to attract central bank loans, enjoy a softer budget constraint, and experience a decline in performance. See also Wang, supra n. 44, at 225.

68. See generally the discussion in Trubek, supra n. 2, at 746-48. 1968).

69. 1 Max Weber, Economy and Society 890 (Guenther Roth \& Claus Wittich eds., 
ible promises not to confiscate and that did not allow others to do what was in effect the same thing.

What about the contract rights half of the Rights Hypothesis? It makes intuitive sense to suppose that a large class of economically advantageous transactions will not take place if there is no legal system in place to enforce the promises parties make to each other. Why is it that this part of the Rights Hypothesis, if not outright wrong, at least has not nearly so much explanatory power as has been claimed for it by its adherents?

Part of the answer, as suggested earlier in this article, may lie in the fact (if it is a fact) that in most economic transactions, third-party enforcement through government coercion is not in fact the only effective enforcement mechanism available, because one-shot deals between people who are and intend to remain strangers are in practice not of great importance in modern capitalist economies. Obviously such a proposition requires empirical support. An excellent study of so-called "relational practices" in Taiwan shows just how very far you can go even in the absence of an effective formal legal system. ${ }^{70}$

The analysis presented here has policy implications in addition to academic ones. The World Bank, for example, now considers "governance" issues in the award of loans, with such issues defined as whether a country has "the rule of law": a system in which

a) there is a set of rules which are known in advance, b) such rules are actually in force, c) mechanisms exist to ensure the proper application of the rules and to allow for departure from them as needed according to established procedures, d) conflicts in the application of the rules can be resolved through binding decisions of an independent judicial or arbitral body and e) there are known procedures for amending the rules when they no longer serve their purpose. ${ }^{71}$

However desirable it might be to have such a system for a number of reasons, it is far from clear that it is the sine qua non of economic development or, more prosaically, the effective use of World Bank loans. ${ }^{72}$

A further policy consequence follows from the relative unimportance of a formal system for the enforcement of contract rights. If a national government has limited resources to devote to growth-enhancing institutions, those resources would be better used in creating

70. Winn, supra n. 23, at 193.

71. Shihata, "The World Bank and 'Governance' Issues in Its Borrowing Members," in The World Bank in a Changing World 85 (F. Tschofen and A.R. Parra eds., 1991), cited in Upham, supra n. 9, at 233. Shihata was General Counsel of the World Bank when he made these remarks.

72. For a spirited critique of "rule of law" rhetoric in policymaking circles concerned with economic development, particularly in the World Bank, see Ohnesorge, supra n. 10. 
an effective structure for the prevention of arbitrary confiscation (either outright or in the form of excessive fees, bribery demands, arbitrary taxes, etc.) instead of for the creation of courts that could fairly adjudicate contract disputes and enforce their decisions. While a fair and efficient court system for the adjudication of contract disputes is no doubt a desirable thing for any country to have, there is a great deal of evidence to suggest that non-governmental actors can set up substitute institutions that do the job reasonably well, even if they do not have the state's monopoly on the legitimate use of force. There is not, however, any such thing as a social remedy for confiscation of one's investment. Thus, businesses need state protection less from each other than from organs of the state. It may be that an advanced level of contractual protection is necessary in advanced economies, but even in advanced economies it appears that a great deal of business is done without resort to court enforcement of contract rights. ${ }^{73}$

At some point, however, we must perhaps admit that the complete absence of a formal legal system in a society is going to have a detrimental effect on economic development that cannot be fully or even substantially remedied by informal social or other sanctions. Yet it would be profoundly misleading to view the real barrier to economic development in such a society as the lack of an effective formal legal system. To say that a society needs enforcement of contract rights in order to get economic development begs the question of what would have to be true about that society for it to be able to have judicial enforcement of contract rights. Arguably, the society needs a commercial culture, an effective tax collection and fiscal disbursement system to pay for courts and judges, a tradition of honesty among public officials, control over crime, and a host of other factors - in short, a whole new society. ${ }^{74}$ Suppose that new society were somehow in place and we observed an upsurge in economic growth: it would be missing the point to give all the causal credit to the judicial enforcement of contracts that came along with those social changes.

73. See, for example, the landmark study by Macauley, supra n. 26, at 55 .

74. On the deeper determinants of economic success, see, inter alia, Hall \& Jones, "Why Do Some Countries Produce So Much More Output per Worker than Others?" 114 Q. J. Econ. 83 (1999) (measuring "social infrastructure" favorable to production); Acemoglu et al., supra n. 43; Rodrik et al., supra n. 43 (finding that the quality of institutions trumps other factors such as geography and openness to trade); Rodrik, "Institutions for High-Quality Growth: What They Are and How to Acquire Them," 35 Stud. Comp. Int'l Dev. 3 (2000) (arguing that there is no single blueprint for the right institutions, but that democratic governance is the meta-institution that results generally in better institutions for growth). 
